\title{
Social Spending in Korea: \\ Can it Foster Sustainable and Inclusive Growth?
}

Selim Elekdag 


\title{
IMF Working Paper
}

Asia and Pacific Department

\section{Social Spending in Korea: Can it Foster Sustainable and Inclusive Growth? Prepared by Selim Elekdag ${ }^{1}$}

\author{
Authorized for distribution by Tom Rumbaugh
}

October 17, 2012

This Working Paper should not be reported as representing the views of the IMF. The views expressed in this Working Paper are those of the author(s) and do not necessarily represent those of the IMF or IMF policy. Working Papers describe research in progress by the author(s) and are published to elicit comments and to further debate.

\begin{abstract}
Going forward, Korea faces two closely related challenges: sustaining economic growth against the backdrop of a rapidly aging population and ameliorating income inequality. This paper argues that a gradual increase in social spending could promote more sustainable and inclusive growth in Korea. In particular, simulation results suggest that social spending which supports labor market reforms can boost longer-term growth. However, despite rapid increases recently - albeit from a low base - there is still a social spending gap relative to Korea's OECD peers. Because of several fiscal challenges in the coming decades, increases in social spending should be incremental, and would be usefully guided by a longer-term fiscal framework.
\end{abstract}

JEL Classification Numbers: E2; E6; O4

Keywords: Korea, growth, social spending, income inequality, fiscal policy Author’s E-Mail Address: selekdag@imf.org

\footnotetext{
${ }^{1}$ The views expressed here are those of the authors and do not necessarily represent those of any institution the author is or has been affiliated with. For insightful comments I am grateful to Silvia Iorgova, Sonali Jain-Chandra, Hoe Ee Khor, Jack Ree, and Thomas Rumbaugh.
} 


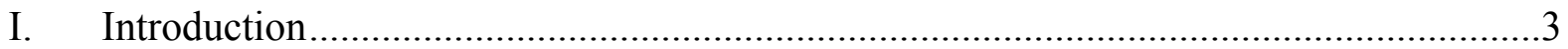

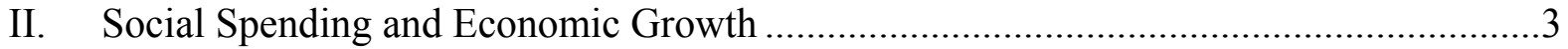

III. How Can Social Spending Promote Sustainable Growth? .........................................5

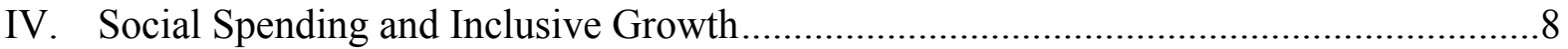

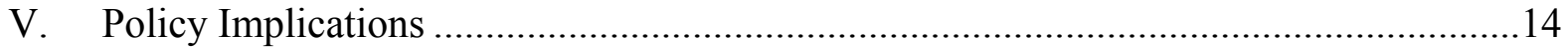

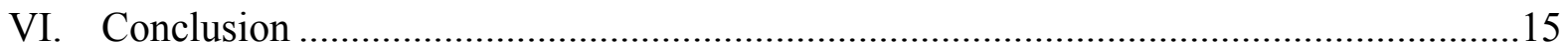

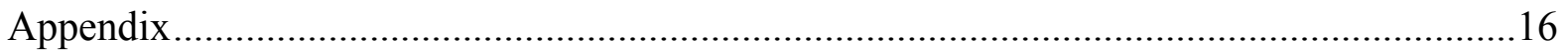

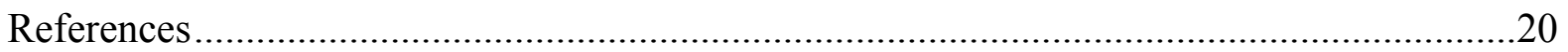

Figures

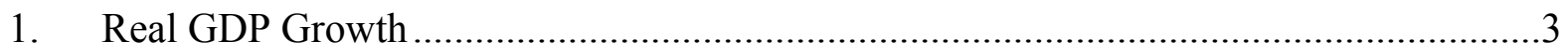

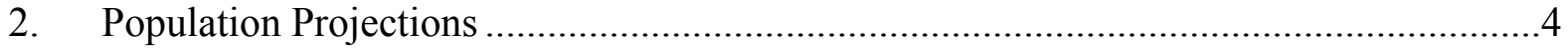

3 Female Labor Force Participation Rates..............................................................4

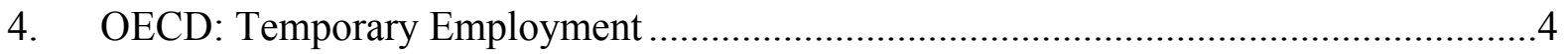

5. Service Sector Productivity Relative to Manufacturing in 2007 ..................................5

6. OECD: Gini Coefficients and Relative Poverty Rates ...........................................

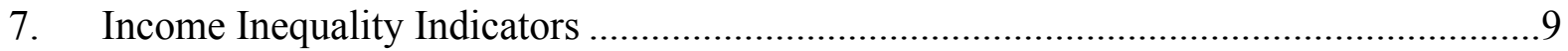

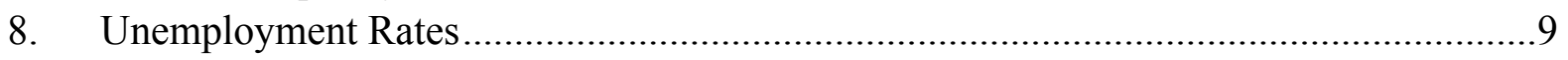

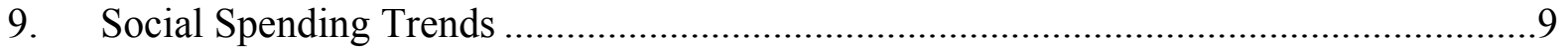

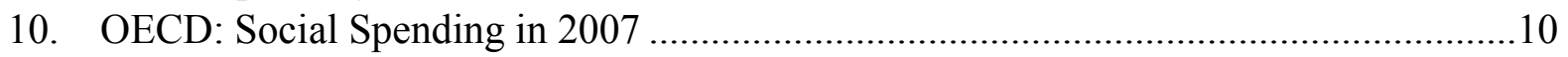

11. OECD: Social Spending Categories in 2007 .......................................................11

12. Selected Indicators Influencing the Social Spending Gap .......................................13

Tables

1. Output Gains From Social Spending-Induced Labor Market Reforms .........................

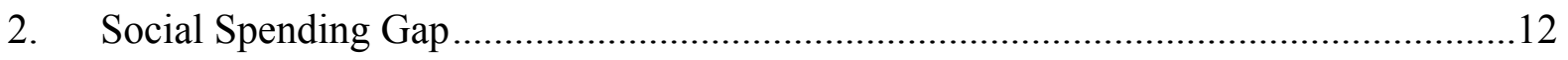




\section{INTRODUCTION}

Looking ahead, Korea faces two intertwined fundamental challenges: sustaining economic growth in the face of rapid population aging and ameliorating income inequality. Against this backdrop, one of the questions this paper attempts to address is whether social spending can reduce income inequality and, at the same time, increase longer-term growth. In most general terms, social spending is related to a broad range of social welfare programs pertaining to healthcare, education, and social safety nets (which, for example, could include pension plans and income support for both the working-age and elderly population). Agreeing on a more specific definition may not be trivial, because, while similarities exist, social spending policies vary across countries.

Social spending can foster more sustainable and inclusive growth in Korea. The argument that growth can help reduce income inequality is well known. However, social spending which improves income equality can also boost growth. As discussed in further detail below, social spending can address the issue of Korea's declining working-age population, help boost productivity (particularly in the services sector), and promote more inclusive growth. In fact, a combination of well-designed social spending policies has the potential to catalyze virtuous cycles whereby lower inequality and stronger growth mutually reinforce each other.

\section{Social SPENDING AND ECONOMIC GROWTH}

Korea has been one of the fastest-growing countries in the world, allowing it to substantially narrow the per capita income gap with other advanced economies (Figure 1). Nonetheless, sustaining the convergence process will become increasingly challenging. This is because Korea, as an advanced industrialized economy, has moved closer to the global technology frontier and has a rapidly aging population. According to the OECD (2012), the convergence in income levels continued despite a slowdown in Korea's potential growth from 7 percent in 1995 to around 4 percent by 2010 . Therefore, unless policies can help prevent the expected

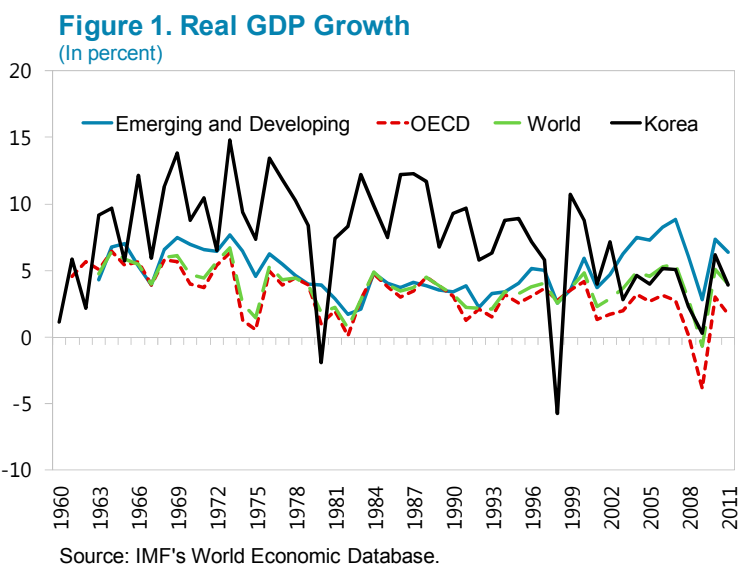
downtrend in productivity and labor inputs, the potential growth rate is expected to decline further.

Social spending can promote sustainable longer-term growth in Korea, by focusing on three related challenges: (i) increasing labor market participation against the backdrop of a rapidly aging population, (ii) reducing duality in the labor market, and (iii) boosting productivity in the services sector. 


\section{Challenge 1: Increasing labor market participation}

While estimates of the precise timing vary, the labor force is expected to peak within the coming decade in line with a decline in the population (Figure 2). The most important strategy to mitigate demographic change would be to increase the female labor force participation rate. For women between the ages of 25 and 54, the labor force participation rate was 62 percent in 2010, the third lowest in the OECD area (Figure 3). Factors that hinder female labor market participation include, among others, a gender wage gap and the lack of affordable, high-quality childcare services.
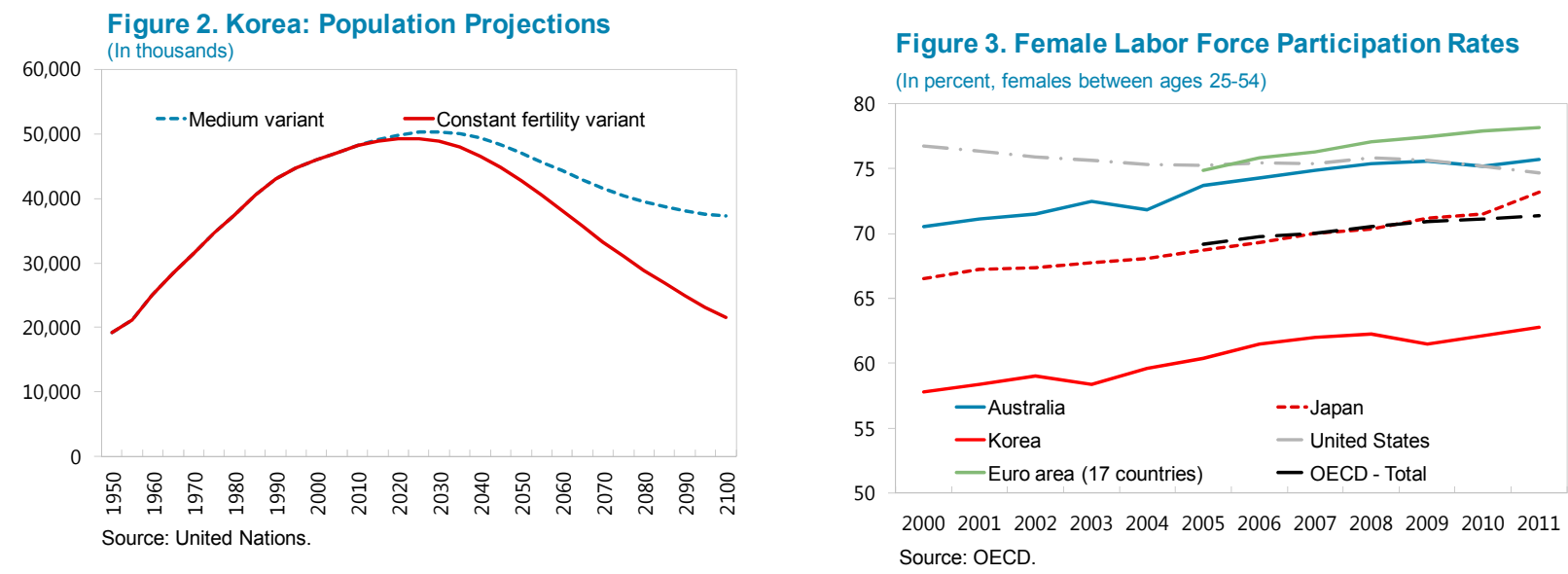

\section{Challenge 2: Reducing labor market dualism}

Along with regular workers, Korean labor market duality stems from the elevated and rising share of non-regular workers - which include temporary workers (Figure 4), a major source of a income inequality (Koske and Wanner, 2011). Korea's rapid integration in a globalized economy, particularly after the mid-1990s, intensified competition, which prompted firms to reduce labor costs and increase temporary hiring, given the difficulty and cost of laying off regular workers (Koh, 2011). While regular workers are characterized by high wages, high employment protection, and broad coverage by the social safety net (and active labor market policies), non-regular workers face low wages, unstable employment, low employment

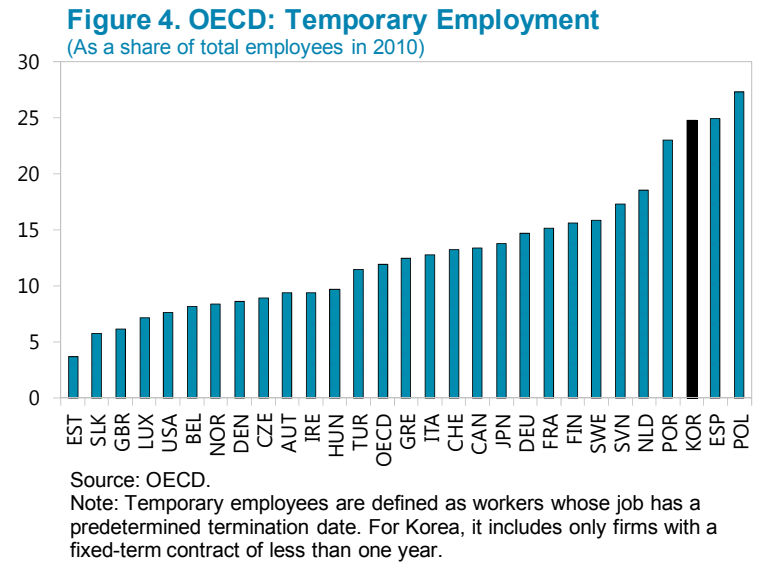
protection, and weak coverage by the social safety net. As a group, non-regular workers tend to be older, less educated, employed in small- and medium-sized enterprises (SMEs), have shorter tenure, and work in the service sector. In addition, women are over-represented, with 42 percent of female employees in non-regular employment compared to 28 percent of males. 
Labor market duality also hinders productivity growth. The largest component of non-regular employment consists of temporary workers, and is associated with increased worker turnover and reduced firm-based training. This lack of firm-based training is compounded by low public spending on training, which is one of the lowest in the OECD area. Low productivity in the service sector translates into lower wages, and because of the disproportionate share of female employees in this sector, further aggravates the gender wage gap and increases in income inequality.

\section{Challenge 3: Boosting productivity in the service sector}

Increasing productivity in the services sector presents an opportunity that would underpin longer-term growth in Korea. Manufacturing has driven Korea's rapid economic development, making it a leading industrial power. In contrast, its service sector, which is dominated by SMEs, is much smaller and markedly less productive (Figure 5). Over the past 25 years nearly 85 percent of GDP growth in high-income countries came from services (McKinsey, 2010). In order for Korea to converge to the income levels in the most advanced countries, making the services sector the second engine of economic growth is required. ${ }^{2}$

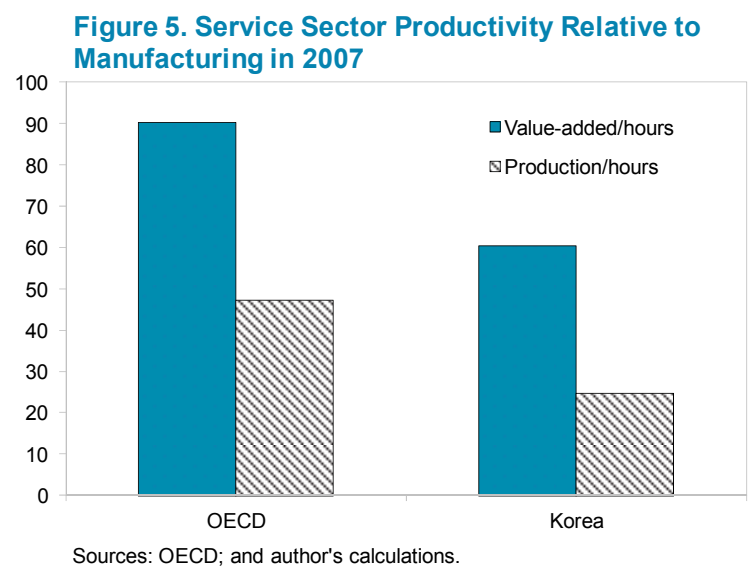

\section{How Can Social Spending Promote Sustainable Growth?}

Education has played a key role in Korea's rapid development. The emphasis on universal access to primary and secondary schools was a factor that contributed to Korea's early growth take-off, and promoted social mobility and income equality (Koh, 2011). Despite these advances, several aspects of the Korean education system raise equity issues, including low investment in pre-primary education and the heavy reliance on private tutoring, among others. Therefore, some aspects of the education system today should be improved, given that policies that promote equal access to education help reduce inequality (OECD, 2012).

Education reform can foster stronger growth over the longer term. For example, expanded vocational training and career consultation outside firms could enhance the employment prospects of non-regular workers and facilitate their transition to regular status. Along with

\footnotetext{
${ }^{2}$ Problems in services are linked to those of SMEs, which account for about 90 percent of service-sector employment. The weakness of SMEs prompted the government to ratchet up support, which has blunted competitive pressures, slowed reform, and reduced the efficiency of resource allocation. Supporting non-viable firms will act as a drag on Korea's growth potential, and should gradually be unwound.
} 
reduced employment protection for regular workers, such reforms would promote a less rigid labor market, facilitate mobility and restructuring, thereby increasing the Korean economy's resilience to shocks. These reforms are in line with the Korean authorities' view as well as some recent initiatives which promote workfare, with the intent of incentivizing work, and thus implementing measures which support training expenses related to skills improvement, provide job-seeking allowances, and offer expanded earned income tax credit (EITC) benefits.

Specific social spending policies can nurture growth in several dimensions. For example, investment in early childhood education and care (ECEC) offers a high return by boosting the later achievement of children. While Korea has expanded public outlays for ECEC, in general, spending on pre-primary education was only 0.2 percent of GDP in 2008, the second lowest in the OECD area (OECD, 2012). Greater ECEC investment would provide a better educational foundation for children from low-income households, which would underpin future productivity gains. At the same time, the greater availability of affordable, high-quality childcare would promote greater participation in the labor market by females, particularly after childbirth. Taken together, targeted social spending policies, such as ECEC, would help increase labor market participation (by females especially), serve to boost productivity (especially in the services sector), and promote sustainable and inclusive growth going forward.

Model-based simulations indicate that social spending which encourages labor market reforms can boost longer-term growth. A general equilibrium model (described in the Appendix) is used to generate illustrative scenarios which show that a more competitive labor market associated with increased social spending implies a higher level of potential output. Social spending policies, including those discussed above, could help reduce duality in the labor market and, at the same time, increase female labor market participation. In turn, these developments would bring about a more competitive labor market with reduced inefficiencies and a greater supply of labor inputs, resulting in a higher potential output. As shown in Table 1 (row F, bottom panel), a less rigid and more competitive labor market could boost potential output by around 1 percent every year over the next decade. In other words, along with addressing inequality, social spending-induced labor market reforms can also boost longer-term growth. 
Table 1. Output Gains From Social Spending-Induced Labor Market Reforms

Potential Ouput Gains Associated with Labor Market Reforms

\begin{tabular}{|c|c|c|c|c|c|c|}
\hline \multirow[b]{3}{*}{$\lambda$} & \multirow{3}{*}{$\begin{array}{r}\text { Markup } \\
\text { (In percent) }\end{array}$} & \multicolumn{5}{|c|}{ Steady-state level of output } \\
\hline & & \multicolumn{5}{|c|}{$\eta$} \\
\hline & & 1 & 2 & 3 & 4 & 5 \\
\hline 3 & 50.0 & 0.8165 & 0.8736 & 0.9036 & 0.9221 & 0.9347 \\
\hline 5 & 25.0 & 0.8944 & 0.9283 & 0.9457 & 0.9564 & 0.9635 \\
\hline 6 & 20.0 & 0.9129 & 0.9410 & 0.9554 & 0.9642 & 0.9701 \\
\hline 9 & 12.5 & 0.9428 & 0.9615 & 0.9710 & 0.9767 & 0.9806 \\
\hline 11 & 10.0 & 0.9535 & 0.9687 & 0.9765 & 0.9811 & 0.9842 \\
\hline 21 & 5.0 & 0.9759 & 0.9839 & 0.9879 & 0.9903 & 0.9919 \\
\hline 51 & 2.0 & 0.9901 & 0.9934 & 0.9951 & 0.9960 & 0.9967 \\
\hline \multirow[t]{2}{*}{101} & 1.0 & 0.9950 & 0.9967 & 0.9975 & 0.9980 & 0.9983 \\
\hline & $\begin{array}{c}\text { Change in } \\
\text { wage markup } \\
\text { (range) }\end{array}$ & \multicolumn{5}{|c|}{$\begin{array}{l}\text { Range of potential output gains } \\
\text { (In percent) }\end{array}$} \\
\hline$[A]$ & $20-5$ & 6.9 & 4.6 & 3.4 & 2.7 & 2.3 \\
\hline [ B ] & $25-2$ & 10.7 & 7.0 & 5.2 & 4.2 & 3.4 \\
\hline
\end{tabular}

Range of potential output gains over the next 5 years (In percent)

\begin{tabular}{lllllll}
\cline { 3 - 6 }$[C]$ & $20-5$ & 1.4 & 0.9 & 0.7 & 0.5 & 0.5 \\
[D ] & $25-2$ & 2.1 & 1.4 & 1.0 & 0.8 & 0.7 \\
\hline
\end{tabular}

Range of potential output gains over the next 10 years

(In percent)

$\begin{array}{lllllll}{[E]} & 20-5 & 0.7 & 0.5 & 0.3 & 0.3 & 0.2 \\ {[F]} & 25-2 & 1.1 & 0.7 & 0.5 & 0.4 & 0.3\end{array}$

Source: Author's calculations.

Note: The value of 1.1 in row $F$, under column with parameter, $\eta$, set to unity implies that a decrease in the wage markup from 25 percent to 2 percent could boost potential output by 1.1 percent per year over the next decade. 


\section{Social SPENDing AND INCLUSIVE GROWTH}

Over the last decade, Korea's high real GDP growth rates have not been sufficient by themselves to fully address the problems of inequality. Between 1960 and the mid-1990s, Korea achieved one of the highest growth rates in the world. At the same time, its income distribution stood out as one of the most equitable among developing countries (Sakong, 1993). Korea's outstanding performance was cited as support for the hypothesis that a positive relationship exists between growth and equity (Alesina and Rodrik, 1994). However, after the recession in the late 1990s, there was a jump in income inequality. Current data indicate that while Korea's Gini coefficient is below the OECD average; its relative poverty rate (another measure of income inequality) was 15 percent in 2008, the seventh highest in the OECD area (Figure 6). ${ }^{3}$

\section{Figure 6. OECD: Gini Coefficients and Relative Poverty Rates}
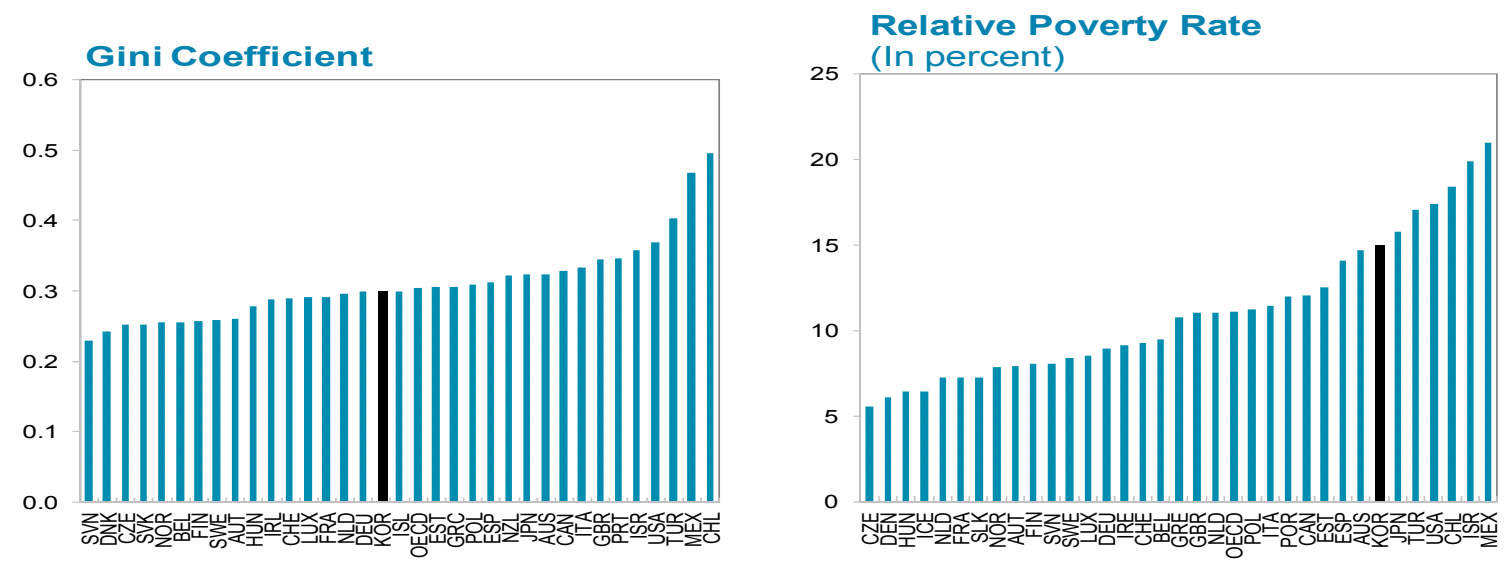

Source: OECD.

Note: Data for late 2000s. The Gini coefficient can range from 0 (perfect equality) to 1 (perfect inequality). Relative poverty is defined as the share of the population that lives on less than half of the median income.

Recent developments suggest that key social indicators are beginning to improve. Despite Korea's high real GDP growth rates, certain measures of inequality such as the Gini coefficient, the relative poverty ratio, and the $\mathrm{LH}$ ratio, have been trending upward over the last decade, indicating deteriorating socio-economic conditions (Figure 7). However, more recently, these unfavorable inequality-related trends seem to have reversed or stabilized. Additionally, after spiking in the late 1990s, the unemployment rate in Korea came back down, and remains at a low level, especially in contrast to the OECD average (Figure 8). The evolution of the unemployment rate in Korea, especially more recently, is a general indicator of improving

\footnotetext{
${ }^{3}$ Recall that the Gini coefficient can range from 0 (perfect equality) to 1 (perfect inequality). The relative poverty ratio is defined as the share of the population that lives on less than half of the median income (and therefore another measure of income inequality). For later reference, the LH ratio measures the share of income of the lowest quintile (richest) to the highest quintile (poorest).
} 
social conditions, and could be taken as a sign that progress in reducing inequality is more enduring.

\section{Figure 7. Korea: Income Inequality Indicators}
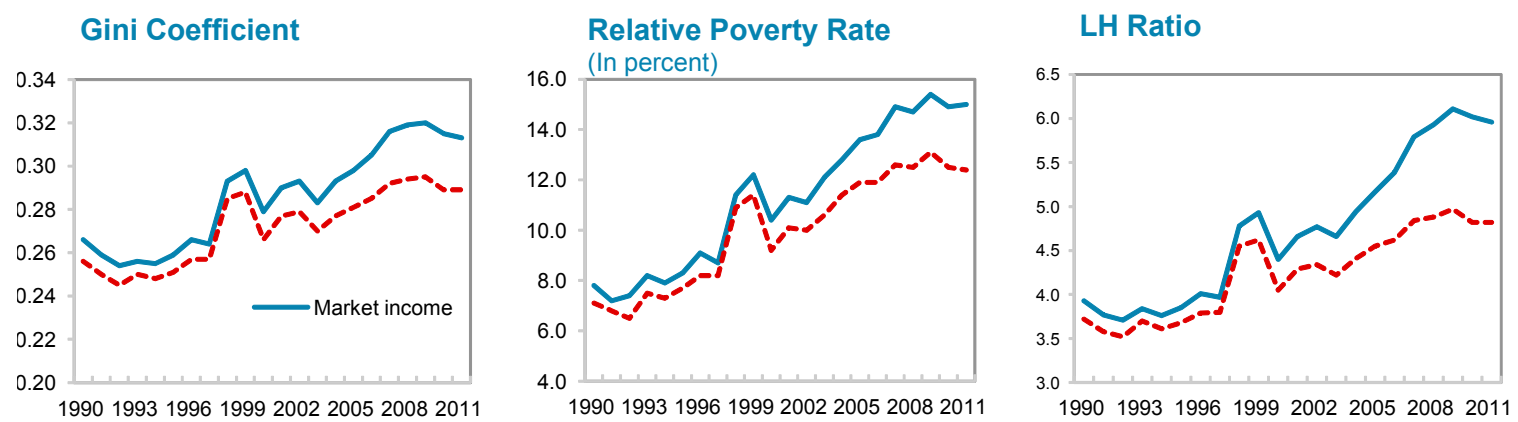

Source: Statistics Korea.

Note: The Gini coefficient can range from 0 (perfect equality) to 1 (perfect inequality). Relative poverty is defined as the share of the population that lives on less than half of the median income. The LH ratio measures that share of income of the lowest quintile (richest) to the highest quintile (poorest).

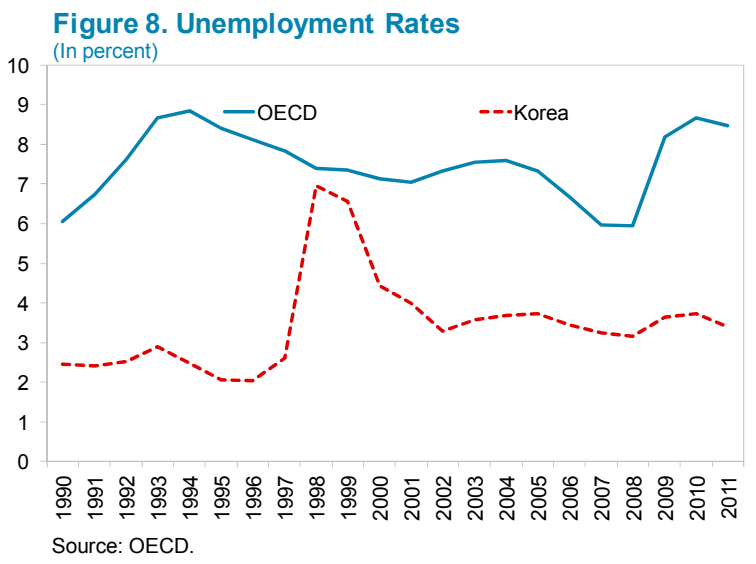

Social spending has increased rapidly, albeit from a low base. Public social spending tripled its share of GDP to 7.6 percent in 2007, from 2.8 percent in 1990 (Figure 9). Nevertheless, this upward trend has not been able to arrest the deterioration in the income distribution over most of the last decade. There are many potential factors responsible for rising inequality, including those related to technological progress and globalization. In the case of Korea, a key factor was the structural change in the economy, including a shift from high-paying jobs in manufacturing to lowerpaying jobs in services. Labor market dualism, which results in large wage gaps between

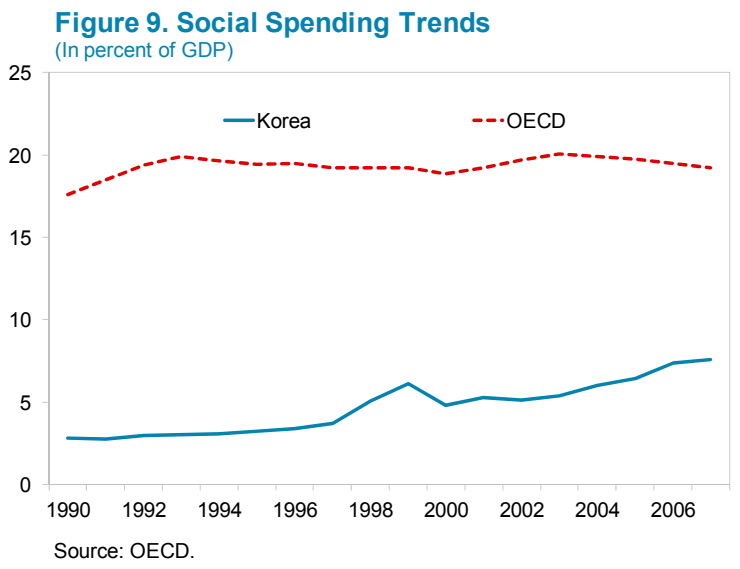
regular and non-regular workers, is another dimension of inequality. These developments motivate the need to reconsider expanding social spending programs and expediting labor market reforms. 
Social spending in Korea is low when compared to its peers across the OECD. In 2007, the latest year with cross-country comparable data available, Korea had the second lowest level of public social spending (Figure 10). In particular, public social spending in Korea was lower than the OECD average in each of the following major areas: health care, pensions, and income support to the working-age population (which include, for example, unemployment benefits, Figure 11). Within the OECD, note also that both family- and old age-related expenditures in Korea rank relatively low.

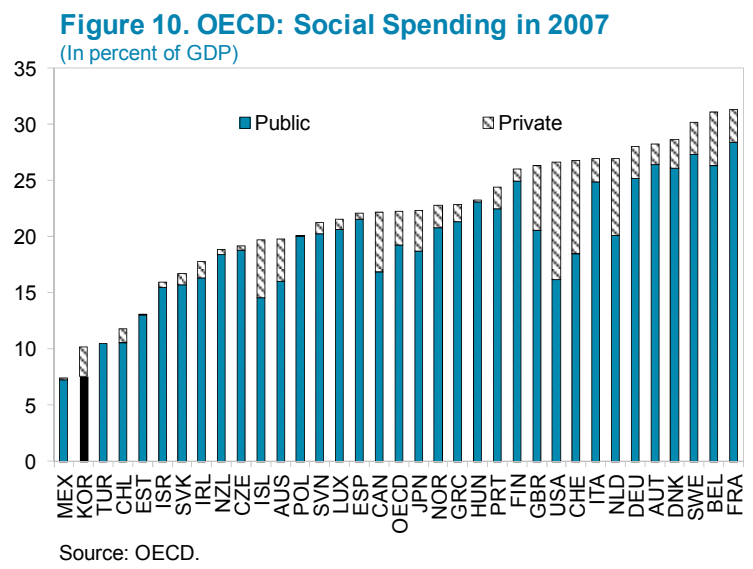


Figure 11. OECD: Social Spending Categories in 2007

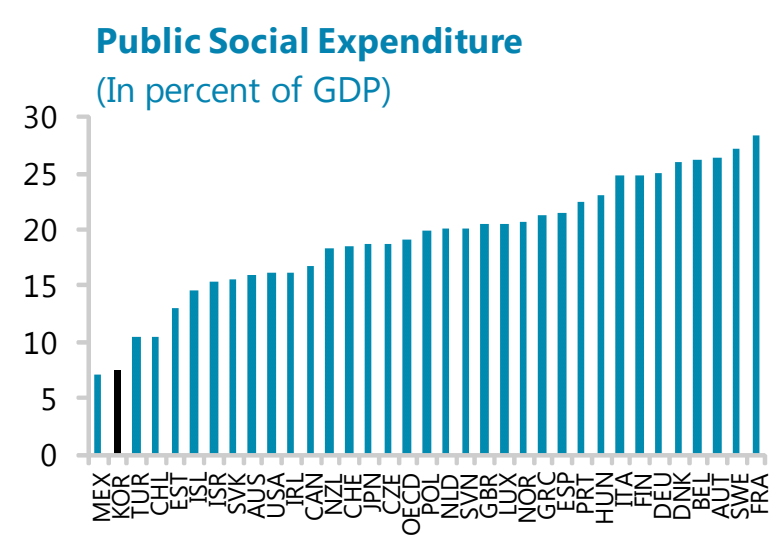

Family-Related Expenditure
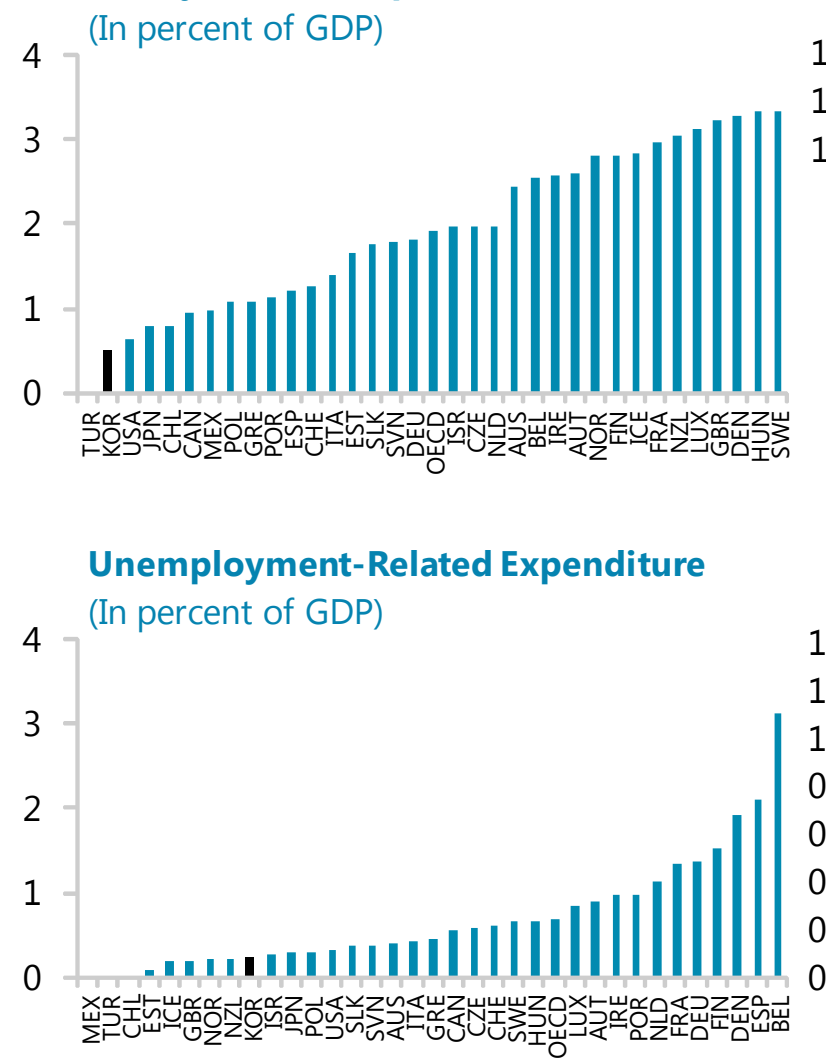

Public Health Expenditure

(In percent of GDP)

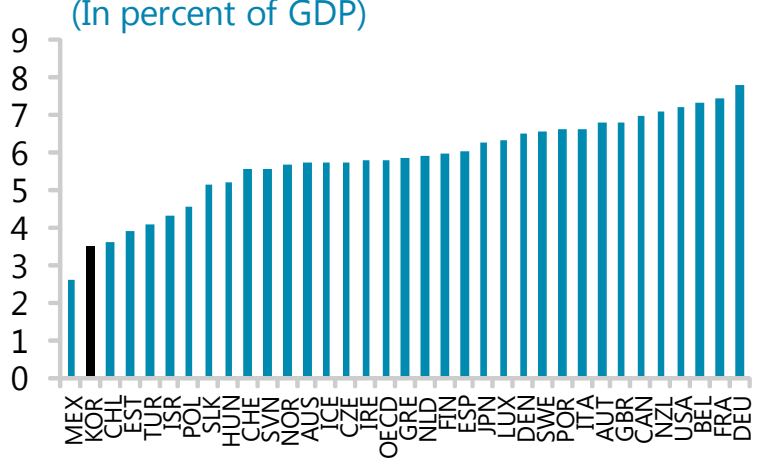

Old Age-Related Expenditure

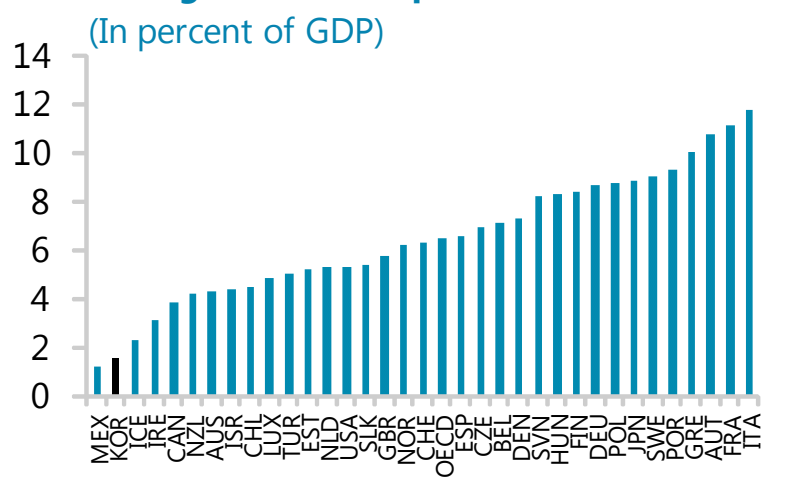

Active Labor Market -Related

Expenditure (In percent of GDP)

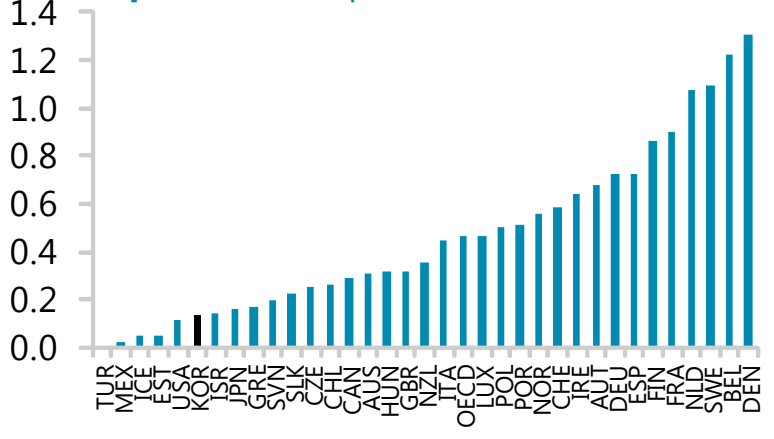

Source: OECD. 
Taking into consideration Korea's specific characteristics suggests a lower social spending gap with respect to the OECD average. An initial comparison of social spending indicates that there is a social spending gap of about 11.7 percentage points of GDP between Korea and the average of its OECD peers. When compared to the OECD average, however, Korea has one of the lowest unemployment rates, currently has a younger population, and despite years of rapid growth, convergence in per capita income is ongoing (Figure 12). Econometric analysis suggests that when these characteristics are factored in, Korea's current social spending needs may be relatively lower. Using the sample of OECD countries, the analysis relates social spending in 2007 to the unemployment rate, per capita income, and a dependency ratio. ${ }^{4}$ When these characteristics are formally taken into account, regression analysis suggests that the social spending gap narrows to about 3.4 percentage points (Table 2). Indeed in the first column, without any explanatory variables, the spending gap is 11.7 percentage points (of GDP). However, when the three main factors which differentiate Korea from the OECD average are taken explicitly into account, the spending gap decreases (as shown under the remaining columns). These results are generally quite robust; in fact, using quantile regressions which control for outliers (the last column) suggests an even smaller social spending gap.

Table 2. Korea: Social Spending Gap

\begin{tabular}{lccccc}
\hline $\begin{array}{l}\text { Dependent variable: } \\
\text { Social spending in 2007 }\end{array}$ & & & & & \\
Explantory variables: & {$[1]$} & [ 2 ] & [ 3 ] & [ 4 ] & [ 5 ] \\
Constant & 19.24 & -0.29 & 6.22 & -5.67 & -5.35 \\
& 20.45 & -0.10 & 1.51 & -1.74 & -1.32 \\
Dependency ratio & & 63.66 & 0.95 & 56.40 & 64.13 \\
& & 7.15 & 2.43 & 6.51 & 4.53 \\
Per capital income & & & 0.0002 & 0.0001 & 0.0001 \\
& & & 3.08 & 2.45 & 0.88 \\
Unemployment rate & 34 & 34 & 34 & 34 & 34 \\
& & 0.61 & 0.26 & 0.69 & 0.49 \\
Number of observations & 11.7 & 4.9 & 5.0 & 3.4 & 3.1 \\
R-squared & & & & 0.60 & 0.34 \\
\hline Social spending gap: & & & & & \\
\hline
\end{tabular}

Source: Author's calculations.

Note: $p$-values below regressions estimates.

\footnotetext{
${ }^{4}$ Using the sample of OECD countries in 2007, public social spending (as a percent of GDP, OECD data), the dependent variable, was regressed against a constant, the unemployment rate, PPP per capita income, and a dependency ratio (population 65 and over divided, by population 30 to 64, UN data). Other specifications, including different variable choices, yield broadly similar results.
} 
Figure 12. Selected Indicators Influencing the Social Spending Gap
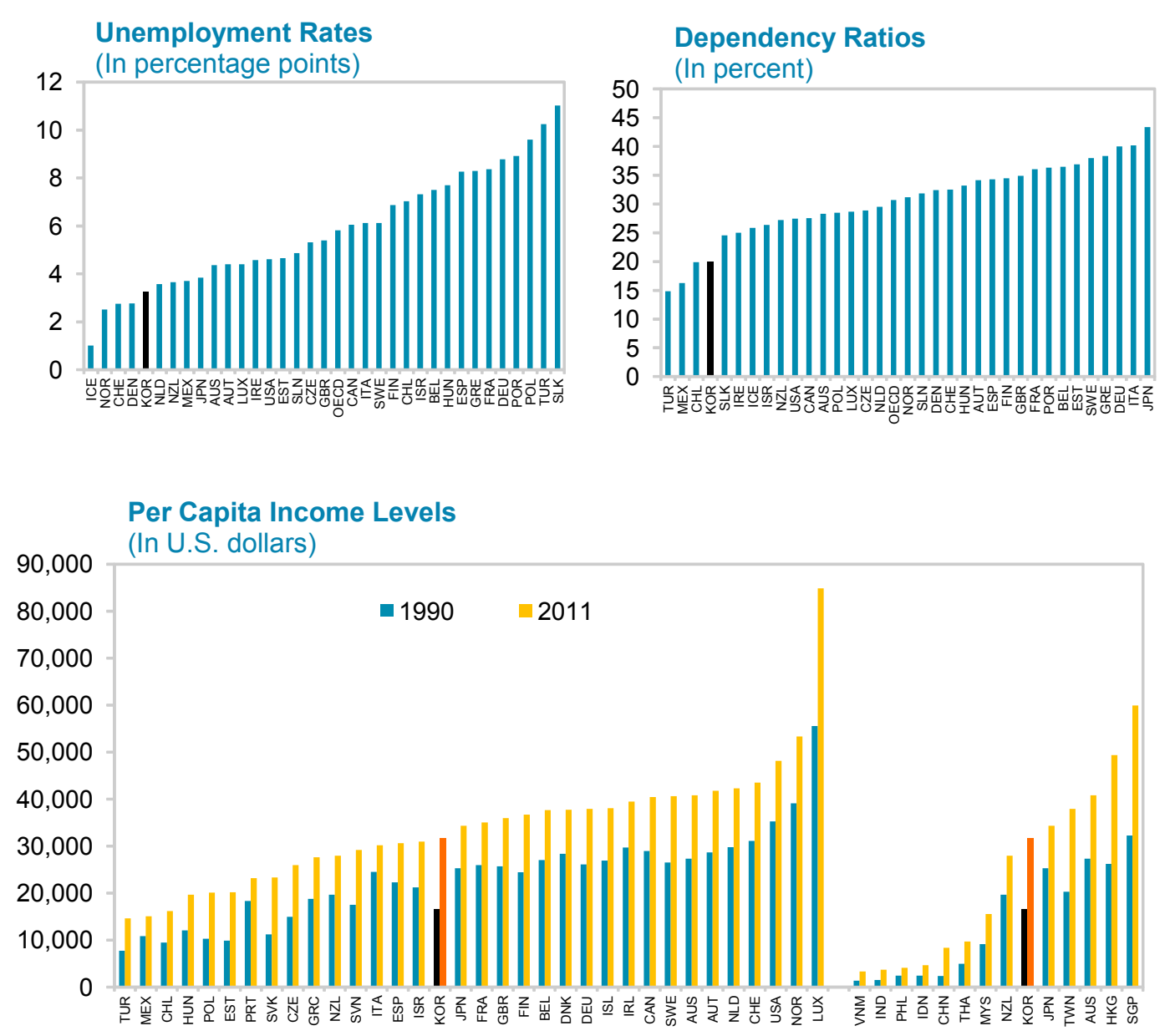

Sources: United Nations, IMF (World Economic Outlook database).

Note: Dependency ratio defined as the population 65 and over, divided by the population between 30 to 64 . Per capita income levels in U.S. dollars adjusted for purchasing power.

To ensure more inclusive growth, social spending should be targeted to help those most in need. ${ }^{5}$ Social spending is not well targeted on low-income households, with only a quarter of cash benefits from the government going to the poorest quintile of the population (OECD, 2012). In addition, as discussed below, spending on health could actually defray the costs associated with a rapidly aging population. Accordingly, social spending priorities that could most effectively promote inclusive growth include the following:

- $\quad$ National Health Insurance (NHI) aims at universal coverage, but is associated with high out-of-pocket payments which are inequitable and regressive because they do not depend on the income of patients. The NHI could therefore be reformed, to promote, among others, healthy ageing, which would limit future healthcare costs as the

\footnotetext{
${ }^{5}$ For additional perspective, see Balakrishnan and others (2011).
} 
population ages. This is critical because, under current policies, population ageing alone is projected to increase expenditures in the form of pensions, health care, and long-term care, by almost 11 percent of GDP over the next 50 years (Feyzioglu, Skaarup, and Syed, 2008).

- $\quad$ The Basic Livelihood Security System (BLSP) is Korea's major welfare program, providing cash and a package of in-kind benefits, including housing, medical and educational benefits to the most vulnerable segments of society. But, under this program, benefits are provided to only 3 percent of the population, suggesting that there is scope for better targeting. In order to increase its effectiveness, BLSP eligibility conditions should be relaxed to cover a larger share of those in need.

- $\quad$ The Basic Old-Age Pension System, introduced in 2008, provides assistance to elderly people who meet the income and asset criteria. At present, around 70 percent of the elderly receive the benefit, which is set at only 5 percent of the average wage, implying that the benefit spreads out resources very thinly over a large segment of the older population, while doing little to reduce income inequality among the elderly. Noting that about 40 percent of the elderly have income below the minimum cost of living (Bae, 2011) suggests that a larger benefit that is more targeted at low-income elderly would be more effective.

- $\quad$ The earned income tax credit (EITC) reduces taxes or provides a refund when the deduction is larger than the tax amount, raising take-home pay at the low end of the income distribution. The EITC is used in a number of OECD countries and is another important tool for reducing income inequality. Therefore, to have a more significant effect on income distribution, the number of recipients and the amount of benefits provided by the EITC should be expanded. The EITC would also make any possible raises in the VAT more equitable.

\section{Policy Implications}

In general, social spending increases should advance incrementally for several reasons:

- In the near term, fiscal consolidation will limit available resources to fund major expansions in social welfare programs.

- Over the longer term, costs owing to rapid population aging and will also put strains on the budget.

- While there may be room for expenditure reallocation (by squeezing non-age-related outlays), there are limits to how much other sending can be reduced, and the government should move cautiously when contemplating increases in social spending given the difficulty of scaling back social spending, as seen in some European countries more recently. 
- $\quad$ Certain revenue measures - including those which could be used to offset cost associated with population aging - may have a negative impact on growth potential. Indeed, pro-growth tax policy which could be used to finance expanded social welfare programs calls for limiting any increase in the tax wedge on labor income and keeping a low corporate tax rate. Given Korea's relatively low VAT rate, and that such taxes generally have a smaller negative effect on labor supply, any increase in the VAT could be combined with an EITC to promote more inclusive growth.

\section{Conclusion}

There seems to be an opportunity to gradually enhance social spending and thereby promote more inclusive and sustainable growth in Korea. While social spending in Korea is low when compared to its peers across the OECD, any increase should be incremental, and accompanied by strengthened revenue performance over the medium term (including by base broadening). Measures should prioritize spending in areas that would increase labor market participation, reduce duality in the labor market, and boost productivity. In sum, a combination of targeted social spending policies would further help reduce income inequality, but also boost potential growth over the longer term. 


\section{Appendix: Model Overview}

This section provides an outline of the general equilibrium model used for the illustrative scenarios relating labor market reforms, increased social spending, and longer-term potential growth. The model is a markedly simplified version of Alp, Elekdag, and Lall (2012) and conducts simulations similar to those presented in Chami, Elekdag, and Tchakarov (2004). In what follows, the goal here is to present the general intuition of the model, leaving the details to the indicated studies.

Using the model, it is argued that as duality in the labor market decreases, implying efficiency gains, lower deadweight losses, and an attendant increase in labor supply (including greater female labor market participation, especially because they account for a disproportionate share of temporary workers). In sum, along with addressing inequality, social spending-induced labor market reforms can also boost longer-term growth.

\section{Firms}

Output is generated using a linear production technology with labor inputs $(L)$ augmented by total factor productivity $(A)$ :

$$
Y_{t}=A_{t} L_{t}
$$

Furthermore, the firm uses a CES combination of differentiated labor inputs. The idea is to capture the notion of labor market duality which is pervasive in the Korean economy. It is difficult and costly to lay off regular workers due to their intrinsic market power as they benefit from higher wages and higher employment protection, in marked contrast to temporary workers.

$$
L_{t}=\left[\int_{0}^{1} \frac{\lambda-1}{L_{i, t}^{\lambda}} d i\right]^{\frac{\lambda}{\lambda-1}}
$$

Here, $L_{i}$ denotes the demand of a differentiated labor input, and the parameter, $\lambda>1$, is the elasticity of substitution among labor inputs. Broadly speaking, the extent of labor input differentiation, and the degree of market power is captured by $\lambda$. In other words, the labor market is characterized by a monopolistically competitive environment. This lack of perfect competition is characterized by a markup, determined by the size of the parameter, $\lambda$, and drives a wedge between the real wage and the marginal rate of substitution between consumption and leisure. As this parameter approaches infinity, labor inputs can be thought of becoming increasingly similar, which erodes the monopolistic structure of the market. The loss of market power is associated with increased labor inputs, reduced deadweight losses, and the eventual perfectly competitive environment is thereby associated with a higher level of potential output.

Firms take the prices of labor inputs as given, and cost minimization implies that the demand for a certain type of labor input is a function of its relative wage: 


$$
L_{i, t}=\left(\frac{W_{i, t}}{W_{t}}\right)^{-\lambda} L_{t}
$$

Where $L_{i}$, is the wage paid for labor input $L_{i}$, and the wage index, $W$, is defined as:

$$
W_{t}=\left[\int_{0}^{1} W_{i, t}^{1-\lambda} d i\right]^{\frac{1}{\lambda-1}}
$$

Against this background, which will be useful below, note that cost minimization by the firm is a standard static problem implying that the real wage equals total factor productivity.

\section{Households}

Within the confines of their budget constraints, households maximize lifetime expected utility:

$$
U_{t}=\mathbf{E}_{0} \sum_{t=0}^{\infty} \beta^{t}\left[\log C_{t}-\frac{1}{1+\eta} L_{t}^{1+\eta}\right]
$$

where household preferences are additively separable in consumption, $C$, and labor effort, $L$, and the discount rate, $\beta$, is bounded by zero and unity. The flow budget constraint states that consumption is limited to the total wage bill, and any residual income, $\Pi$, (for example, stemming from labor union premiums):

$$
C_{t}=\frac{W_{t}}{P_{t}} L_{t}+\Pi_{t}
$$

Because the focus is on comparative static simulations, borrowing and saving by the households was not necessary for the purposes here, and thus not modeled. As with other many features of this model, this is another dimension that could be readily developed.

As discussed above, each household is the monopolistic supplier of a differentiated labor input. Given their market power, households set the nominal wage for their specific labor input facing a downward-sloping demand curve.

\section{Solution}

Overall, in the steady state, the model boils down to four key equations: the production function, the budget constraint, the condition linking the real wage and total factor productivity, and equation stating that the real wage is equal to the marginal rate of substitution between consumption and leisure, but augmented with a markup. Note that with $\lambda=11$, for example, the gross markup, $\lambda /(\lambda-1)$, takes a value of 1.1 (implying real wages that are 10 percent higher than under a perfectly competitive labor market). 


$$
\begin{gathered}
Y=A L \\
C=\frac{W}{P} L+\Pi \\
\frac{W}{P}=A \\
\frac{W}{P}=\frac{\lambda}{\lambda-1} C L^{\eta}
\end{gathered}
$$

Because total factor productivity is exogenous, $A$, is essentially unity, and the system can be solved for output as follows:

$$
Y=\left[\frac{\lambda-1}{\lambda}\right]^{\frac{1}{1+\eta}}
$$

In sum, the steady-state level of output, or for our purposes, potential output, depends on the calibration of two parameters, of which, the elasticity of substitution among labor inputs, the parameter, $\lambda>1$, is most critical. Studies estimating structural model developed to capture salient features of the Korean economy by Elekdag, Justiniano, and Tchakarov (2006), and Alp, Elekdag, and Lall (2012) find that while the parameter, $\eta$, can range between 1.5 and 2.5 , the substitution elasticity, $\lambda$, is typically in the 7 to 9 range, implying a wage markup of around 15 percent, in other words, the labor market is characterized by a notable degree of monopolistic competition.

\section{Model Simulations}

Can lower labor market rigidity boost potential growth? Using the model, illustrative scenarios are generated which show that a more competitive labor market — brought on, in part, by higher social spending - implies a higher level of potential output. As duality in the labor market decreases, this implies efficiency gains, less deadweight losses, and a likely increase in female labor market participation (as they account for a disproportionate share of temporary workers). To do so, we start off with a high degree of monopolistic competition in the labor market as set the elasticity, $\lambda$, to three as shown in Table 1. Then the elasticity is increased, corresponding to a more competitive labor market (with an attendant decrease in duality). While the elasticity maybe a relatively abstract notion, the implied markups are also included in the table to facilitate intuition. Notice that as the elasticity increases (implying that labor inputs are more readily substitutable), the wage markup decreases as market power is eroded owing to labor market reforms.

A less rigid labor market implies a higher level of potential output. As shown in the table, if wage markups decrease from 25 percent (in line with the estimated values found in the studies cited above) to 2 percent, potential output could increase by 10.7 percent (row [ B ] in the bottom panel, with $\eta=1$ ). These are gains over the long run, but if it is assumed that they could 
be materialized in the next decade, this implies a boost to potential output by around 1.1 percent every year (under same column with $\eta=1$, in row [ F ]). Note that this main message is robust to other parameter choices. Taken together, social spending-induced labor market reforms can ameliorate income inequality and also boost longer-term growth. 


\section{References}

Alesina, A. and D. Rodrik, 1994, "Distributive Politics and Economic Growth," The Quarterly Journal of Economics, Vol. 109.

Alp, Harun, Selim Elekdag, and Subir Lall, 2011, "Did Korean Monetary Policy Help Soften the Impact of the Global Financial Crisis of 2008-09?" IMF Working Paper, 12/5 (Washington: International Monetary Fund).

Bae, J. ,2011, “Korean National Pensions: Facts and Functions in 2009," in Economic Crisis and Social Integration, Vol. 1.

Balakrishnan, R., C. Steinberg, and M. Syed, 2011, “Asia's Quest for Inclusive Growth,” Asia and Pacific Regional Economic Outlook, October, (Washington: International Monetary Fund.

Chami, Saade, Selim Elekdag, and Ivan Tchakarov, 2004, "What are the Potential Economic Benefits of Enlarging the Gulf Cooperation Council?” IMF Working Paper, 04/152 (Washington: International Monetary Fund).

Elekdag, Selim, Alejandro Justiniano, and Ivan Tchakarov, 2006, “An Estimated Small Open Economy Model of the Financial Accelerator," IMF Staff Papers, International Monetary Fund, Vol. 53, pp. 219-41.

Feyzioglu, T., M. Skaarup, and M. Syed, 2008, “Addressing Korea’s Long-Term Fiscal Challenges," IMF Working Paper 08/27 (Washington: International Monetary Fund).

Koh, Y., (2011), “Social Safety Net in Korea: From Welfare to Workfare,” Korea Development Institute, mimeo.

Koske, I. J. Fournier, and I. Wanner (2011), "Less Income Inequality and More Growth-Are They Compatible?: Part 2, The Distribution of Labour Incomes," The Organisation for Economic Co-operation and Development (OECD), Economics Department Working Papers, No. 925, OECD, Paris.

McKinsey \& Company (2010), "South Korea: Finding Its Place on the World Stage," McKinsey Quarterly, April.

The Organisation for Economic Co-operation and Development (OECD), 2012, OECD Economic Survey of Korea, OECD, Paris.

Sakong, Il (1993), Korea in the World Economy, Institute for International Economics, Washington, DC. 